\title{
IAMJ
}

INTERNATIONAL AYURVEDIC MEDICAL JOURNAL

\section{ROLE OF RASAYANA IN RELATION TO CORONA VIRUS (COVID - 19) DISEASE}

\author{
Pooja Pawar ${ }^{1}$, Sanjay Srivastava ${ }^{2}$, Rajesh Jain ${ }^{3}$ \\ ${ }^{1}$ PG Scholar, Rog Nidan \&Vikriti Vigyan \\ ${ }^{2}$ Professor and HOD, Rog Nidan \& Vikriti Vigyan \\ ${ }^{3}$ Lecturer, Rog Nidan \& Vikriti Vigyan \\ Pt. Khusilal Sharma Government (Autonomous) Ayurveda Institute, Bhopal, Madhya Pradesh, India
}

Corresponding Author: poojapanwar9632@gmail.com

https://doi.org/10.46607/iamj2209022021

(Published online: February 2021)

Open Access

(C) International Ayurvedic Medical Journal, India 2021

Article Received: 30/01/2021 - Peer Reviewed: 01/02/2021 - Accepted for Publication: 10/02/2021

\section{Check for updates}

\begin{abstract}
The pandemic outbreak of COVID - 19 came with extensive health related hazards which lead to economical and psychological problems like fear, stress, sadness, anxiety, depression among the people and is a challenge for humanity to face and fight this comorbidity. Various clinical Observations indicate the interaction of SARS CoV- 2 viruses with the immune system which plays a significant role in determining the outcome of infection and it is responsible for controlling the immunopathogenesis of coronavirus infection. Early control of this contagious disease within the host, limits its spread. Yet no system of medicine has any evidence-based treatment for COVID 19. All the doctrine of medicine in the world has tried to develop effective strategies to overcome this disorder. Panchakarma and Rasayana therapy are indicated as an effective management plan for Janpdhodhwamsa Vyadhi (epidemic disease). Preventive use of Rasayana in Corona virus in the current scenario to build strong immunity in the peoples and to explore how it modifies the immunity along with use of certain recipes for its management
\end{abstract}

Keywords: COVID - 19, immunity, Rasayana etc.

\section{INTRODUCTION}

On $30^{\text {th }}$ January 2020, World Health Organization has declared novel coronavirus disease (COVID - 19) pandemic as a global health emergency for all world communities, which is an infectious disease caused by 
Severe Acute Respiratory Syndrome Coronavirus 2 (SARS-CoV-2).

It has now spread globally all over the world in 221 countries with more than, 103, 672, 967 confirmed cases and 2,241,041deaths and in India,10,764,177 confirmed cases and total deaths 154,472 as on dated 2 February $2021^{1}$.

Coronaviruses have become the greatest threat to the health of all human beings, and it has put the global economy into a recession, along with the effect on the global environment. In the last two decades the world suffered some diseases which were caused by different viruses belongs to the subfamily Coronavirinae in the family Coronaviridae like. Severe acute respiratory syndrome coronavirus (SARS - CoV) occurred in 2002 and Middle East respiratory syndrome coronavirus (MERS - CoV) was first identified in 2012, with mortality rates of $10 \%$ for SARS - CoV and $37 \%$ for MERS CoV. ${ }^{2}$

Current estimated mortality of COVID - 19 for the overall infected population is $0.25-3.0 \%$ whereas it increases to $>14 \%$ among elderly (over 80 years), $10 \%$ in associated CVD and 7\% in associated diabetes. In 5\% cases requiring Intensive care, the disease progression is gradual, and requires about 9-10 days to progress from symptoms of Upper Respiratory Tract Infection (URTI) to Acute Respiratory Distress Syndrome (ARDS). ARDS often is followed by un-correctable hypotensive shock, multi-organ failure and eventually death. $^{3}$

COVID - 19 is a communicable disease for which no register treatment plan is available, however recently vaccine is introduced but its availability is limited.

By several observations and Study, it has been proved that coronaviruses particularly affect the immune system and lower the immune responses of the body. Those people who have low immune systems come under the risk of this disease. Physicians and Doctors of the world are trying to stop the spread of pandemics, thus it's a need of time to provide clinically proven prophylaxis and therapeutic strategy. The dimensions of pandemic need an extreme utilization of all medical systems available in the world.
In Ayurveda the concept of communicable disease and its management is well defined in Charak Samhita, Viman Sthan under Janapadodhwamsa. Corona is a contagious disease which comes under the Janpdhodhwamsa Vyadhi. In the present scenario human life has been terrifically affected by corona virus therefore it's a challenge for humankind to survive in this condition. For this situation preventive use of Rasayana therapy as a prophylaxis can be introduced because the corona virus mainly affects the human immune system and Rasayana has the power to increase immunity by promoting inner defence power of individuals. Several herbal formulations and its different preparations have been mentioned in ayurvedic text which acts as $R a$ sayana. It has vigour to influence the immune effectors cells i.e. lymphocytes, macrophages, dendritic cells, natural killer cells, cytotoxic T lymphocyte cells by virtue of which they work as immunomodulators. The $R a$ sayana Dravya provides strength against the viral condition and improves the immune response against this pandemic disease that's why Rasayana therapy is an option for novel coronavirus. ${ }^{4}$

\section{Aim and Objectives:}

This article aims to provide information about the preventive role of Rasayana Dravayas to build up immunity against coronavirus and use of certain recipes for its management.

\section{Material \& Methods:}

All the available literatures in Ayurveda as well as current updates related to COVID - 19.

\section{Novel Coronavirus and Its Pathogenesis:}

It is known as the Severe Acute Respiratory Syndrome Coronavirus 2 (SARS CoV - 2). It belongs to the coronavirus family. Structurally, it is a positive sense single stranded RNA virus, has $50-200 \mathrm{~nm}$ in diameter. In humans, the mode of transmission is respiratory secretions directly through the droplets from coughing and sneezing within 2 meter and indirectly through the contaminated surfaces or objects. It enters the human body through the nose, mouth or eyes and through breathing these particles reach to the lower respiratory tract. SARS CoV-2 has four structural proteins: Spike (S), Envelop (E), Membrane (M) and Nucleocapsid (N) in 
which the first three are the viral envelope and $(\mathrm{N})$ is the RNA genome.

The spike proteins of the coronavirus stick on epithelial cells that line the respiratory tract as well as those in the air sacs in the lungs. SARS-CoV -2 is able to stay undetected longer than many flu or coronaviruses and its spike proteins are able to gain entry by unlocking the ACE2 protein on the lung cells. The cell's proteaseTMPRSS2 opens the spike protein of Virus, Virion releases RNA into the cell \& Forcing cell to produce copies of the virus $\&$ infect more cells. At least three virulence factors produce $\&$ promote shedding virion from host cells and inhibit Immune Response. ${ }^{5}$

Due to spread of infection in more air sacs, the lungs find it harder to perform their core job of extracting oxygen from the air, and eventually, this aggravates breathlessness, which results in inflammation and due to fluid accommodation leads to pneumonia. Cytokine storm is considered to be one of the major causes of multiple-organ failure in COVID-19 infections. Excessive infiltration of the inflammatory cells like monocyte and neutrophil into lung tissue will lead to lung injury. Another source of damage to the lung is through cytokine-induced apoptosis of lung epithelial cells.

IFN- $\alpha \beta$ and IFN- $\gamma$ induce inflammatory cell infiltration through two major mechanisms involving Fas-Fas ligand (FasL) or TRAIL-death receptor 5 (DR5) and cause the apoptosis of airway and alveolar epithelial cells. This will lead to alveolar edema and hypoxia and hence cause acute respiratory distress syndrome (ARDS). ${ }^{6}$ In acute stage, it can also lead to depletion of the frontline white blood corpuscles tasked with fighting the infection and making the body vulnerable to other secondary infections, which may lead to death. In COVID - 19 the symptoms like fever, cough, sneezing, fatigue and shortness of breath are very much similar to flu. Upper respiratory symptoms like sore throat, rhinorrhoea, and Gastrointestinal tract symptoms like diarrhoea nausea, vomiting is also reported. Among those who develop symptoms, mostly (about $80 \%$ ) recover from the disease without needing hospital treatment. About $15 \%$ become seriously ill and require oxygen and 5\% become critically ill and need intensive care. ${ }^{7}$ Complications leading to death may include respiratory failure, acute respiratory distress syndrome (ARDS), sepsis and septic shock, thromboembolism, and/or multiorgan failure, including injury of the heart, liver or kidneys. ${ }^{8}$

People aged $\geq 60$ years and the peoples with weak or poor immune function and having disease such as diabetes, cardiovascular disease, chronic respiratory disease, cancer, renal, and hepatic dysfunction are at higher risk for severe COVID-19 than children who might be less likely to become infected. ${ }^{9}$

\section{Immunity in Ayurveda:}

Immunity is a link between good health and diseased condition of the body and is well defined under the heading of Vyadhikshamatva. Vyadhi means disease and Kshamatva means resistance. Acharya Chakrapani Datta has interpreted the term Vyadhi-kshamatva as Vyadhi bala Virodhitwa i.e., reducing the strength of the already manifested disease and Vyadhyutpada Pratibandhakatwa i.e., prevention of the unmanifested disease Therefore, Vyadhikshamatva means the factor which limits pathogenesis and opposes the strength of disease. Vyadhikshamatva depends on the presence of Bala or Oja in the body. Therefore, factors which protect and strengthen the Oja, contributes to increased immunity are Satmya Aahara (suitable diet) Vyayama (exercises) and Rasayana (rejuvenation) Sevan. Rasayana drugs have influences on Oja which increases Sharir Bala. In the present scenario of corona pandemic $R a$ sayana Sevan is a good option to promote and boost up immunity. The use of Rasayana for improving the overall resistance of the body against common infections and pathogens has been a guiding principle of Ayurveda. It improves immunity by resisting the disease on both mental and physical aspects.

Rasayana As An Immunity Builder Against Corona: Rasayana Chikitsa is a branch of Ashtanga Ayurveda, which fulfils both the aims of Ayurveda prevention and promotion of health. As per Charak Samhita, Rasayana is the way for attaining excellent Rasadi Dhatus ${ }^{10}$ and as per Acharya Sharangadhara, Rasayana treatment is one which result in the prevention of diseases due to old age. ${ }^{11}$

"Rasayana" plays a major role as rejuvenators, nutritional supplements, and possess strong antioxidant 
activities. It also exerts antagonistic action on oxidative stressors, giving rise to the formation of different free radicals. ${ }^{12}$ Majority of Rasayana drugs have several essential phytoconstituents like, riboflavin, beta carotene, Vitamin C, Vitamin E etc. It increases natural immunity, improves the functions of all fundamental organs of the body and keeps the sigh of early ageing at bay. Due to these, by the use of Rasayana, the risk of atherosclerosis, cancer, diabetes, rheumatoid arthritis and several autoimmune diseases have been decreased.

Corona generally affects the immune system, respiratory and gastrointestinal system and Rasayana has the property to act as antimicrobial, antioxidant, anti-stress, anti-inflammatory, and grant immunity ${ }^{13,14}$, against disease. All these properties of Rasayana indicate a better option for prevention of coronavirus. Thus, $R a-$ sayana is an answer for mental and physical resistance development against the impact of corona.

\section{Immunomodulatory Action of Rasayana Dravayas:}

An immunomodulator can be defined as a substance, which can influence any constituent or function of the immune system in a specific or nonspecific manner including either innate or adaptive arms of the immune response. They are a diverse array of recombinant, synthetic and natural preparations, often cytokines. ${ }^{15}$

Some medicinal plants modulate immune mechanism by either stimulate the immune system, (e.g., Panax ginseng, Ocimum sanctum, Tinospora cordifolia, and Terminalia arjuna), and by suppress the immune response Alternanthera Tenella Mechanisms of immunomodulation activity occur mainly via one or more of the following steps; antigen recognition and phagocytosis, lymphocyte proliferation/ differentiation, synthesis of antibodies, antigen - antibodies interaction, release of mediators due to immune response, modification of target tissue response.

The phytochemical analysis of plants shows that herbal Rasayana drugs contain polyphenols, tocopherol, tannic acid, ascorbate, carotenoids, flavonoids, etc., which have been seen to have vigorous immunomodulatory properties.

The herbal formulation of Indian traditional medicine due to immunomodulatory properties of their content may stimulate immunomodulation which probably act synergistically. This hypothesis along with the lack of toxicity can be important to understand their use in the past as well as currently. Rasayana Dravaya as work as immunomodulator, immune stimulant, antioxidant, and antistressor agent. The Rasayana herbs perform their action by immunostimulant, immunoadjuvant, and immunosuppressant properties or by affecting the immune response.

\section{Type of Rasayana:}

Naimittika Rasayana is disease specific and is utilized for specific curative purposes by its Vyadhi Harana property, e.g. Shilajit in Madumeha (Diabetes mellitus), Khadira, Bakuchi in Kushta (skin disorders).

Ajasrika Rasayana, promoter of health by some drug regimen and can be consumed in all conditions. It involves utilization of milk, ghee, honey and maintenance of a disciplined lifestyle.

Kamya Rasayana, is used to improve functions like, Kama desire. It also improves Prana (life energy). Medhakamya; used for enhancing the memory and intellect.eg. Shankhapushpi. AyushKamya; used for increasing longevity.

\section{How Rasayana Dravya Work:}

Corona virus belongs to the subfamily Coronavirinae in the family Coronaviridae, so it also spread rapidly and produces serious infectious diseases like, pneumonia, ARDS, etc. and become a threat to human health like other viruses of this family. When our body is exposed to any virus for the first time the immune system gets impair and cannot work properly and the person gets sick. The same phenomena have happened in the case of COVID-19 ${ }^{16}$

An efficient immune system must have the ability to adopt in strange environmental changes to fight against infections. The immune system neutralizes an infection by producing antibody for fight against disease like corona, so there is need to find an effective therapeutic measure using the accumulated knowledge of the innate immune response system. The use of Rasayana Chikitsa is vast and very effective in the prevention as well as management of infectious disorder. "Rasayana" possess strong antioxidant activities and plays a major role as, rejuvenators, nutritional supplements, It also exert antagonistic action on oxidative stressor which 
give rise to the formation of different free radicals. ${ }^{17} \mathrm{By}$ this property it act on the level of tissues and helps to provide good immunity to healthy person. In diseased person Rasayana Dravyas acts at the level of Srotas (body channels) thus helps in breaking the pathogenesis of disease like corona by removing vitiation of body channels. ${ }^{18}$

\section{Example of Some Rasayana}

Kaali Mirch (Piper nigrum):

Antiviral properties have been proved, against viruses responsible for infection in the respiratory tract, its key alkaloid components piperine and 10 piperamides can be the potential phytochemicals that can help in the fight against COVID-19 which is also a respiratory tract infection. ${ }^{19}$

\section{Guduchi (Tinospora Cordifolia):}

Due to its alkaloid components including tinosporin, tetrahydropalmatine, choline, palmatine and magnoflorine, it also has protective role against aflatoxin induced nephrotoxicity. With their broad beneficial activity, it plays important role to improve our immune system to fight against infectious diseases. ${ }^{20}$

\section{Amalaki (Emblica Officinalis):}

Amalaki (Indian Gooseberry) is the richest source of Vitamin $\mathrm{C}$ and natural antioxidant. It contains antioxidant, Vitamin C, Tannin and Gallic Acid. In Charak Samhita Amalaki has been kept in KasaganaVarga ${ }^{21}$, so it useful in recurrent respiratory tract infections mainly in seasonal cough and cold, tonsillitis, sinusitis and sore throat. The dry extract of Emblica officinalis exhibit the antitussive activity not only due to Antiphlogistic, Antispasmolytic and Antioxidant efficacy effects but also to its effect on mucus secretion in the airways. $^{22}$ Emblica officinalis has an immune activation property which is an effective as well as protective approach against emerging infectious diseases.

\section{Haridra (Curcuma Longa)}

The most effective compounds are curcumin, arturmerone and zingiberene. Curcumin 's antiviral properties are due to its inhibitory role towards virus RNA replication which leads to reduction in the viral load. It also has excellent anti-inflammatory properties and also reported to strengthen the immunity. ${ }^{20}$
Ashwagandha (Withania somnifera),

Ashwagandha has main chemical constituents of phytochemicals namely withanolides which includes triterpenelactones-withanolides, withaferin $\mathrm{A} \& \mathrm{D}$, steroidal lactones, alkaloids, tropine and cuscohygrine, respectively. According to Ayurveda experts, it is reported that Whithanone reduces the electrostatic component of binding free energies of ACE2-RBD complex and thus block or weakens the COVID-19 entry and its subsequent infectivity. It is also reported that the host cells namely ACE 2 in the human body got entrapped by SARS-CoV-2 with the help of its spike protein Receptor-Binding Domain (RBD). Basically, it blocks the host protein interactions. Indirectly the triple combination helps to boost the immunity against the COVID19 infection. ${ }^{23,24}$

\section{Some Rasayana For Different Stages of Corona: Unexposed Asymptomatic Group:}

Rasayana therapy along with physical and social distancing from infected persons. Maintain hygiene. Gargle with warm water added with a pinch of turmeric and salt, and Yashtimadhu. Practicing good respiratory hygiene, for these takes Rasayana may include Brahma Rasayana, Chyavanprasha daily.

\section{Exposed Asymptomatic (Quarantined) Group:}

This group comprises of people who are without apparent symptoms, but at risk due to contact history. Intake of comfortable warm fluids boiled with medicinal herbs (preferably Shunthi, Dalchini, Trikatu) should be used as a regular drink to maintain hydration. combination of Guduchi (Tinospora cordifolia), Shunthi (Zingiber officinale) Haridra (C. longa). and Ashwagandha for Aampachana and Agnideepan in order to prevent the progression of pathogenesis in its initial SanchayaPrakopa-Prasara stage. Using antiviral Rasayana drugs such as Ocimum sanctum, Glycyrrhiza glabra, Adhatoda vasica, Andrographis paniculata, Swertia chirata, Moringa oleifera, Triphala and Trikatu. Chyawanprash Avaleha, Indukantam Grutham, Haridra Khanda is used. ${ }^{25}$

With Mildhigh-Risk Group Covid - 19 Symptoms: This category relates to people found positive to SARSCoV-2 and are having mild URTI symptoms. In treatment such medicine is given which can cause balance 
in the vitiated Dosha to control disease progression. Formulations like Maha Sudarshanghan Vati, Amritarist, Samshamani Vati Rasnasaptak, Ashwagandharishta Lakshmi Vilas Rasa, Pippali Rasayana, Sanjeevani Vati, Gojihwadi Kashaya, Vyaghri Haritaki, Kantakari Avaleha, Dashmool Kwath, Sitopaladi, Talishadi, and Yashtimadhu, are may be the most suitable drugs to be used at this stage.

With Moderate To Severe COVID - 19 symptoms: Patients who belong to high risk groups came in this category. Patients Which have severe symptoms like acute respiratory syndrome, pneumonia etc are given Pushkaramoolasava, Agastya Haritaki, Vyaghriharitaki, Chitrak Haritaki Avaleha, Kantakari Avaleha, Shwas Kuthar Rasa, Pippali Rasayana, Jaimangal Rasa. ${ }^{26}$

\section{DISCUSSION}

Novel corona is a critical situation for all the world's communities. It very rapidly spreads and infects people. It is a proud moment for all of us that currently multiple COVID - 19 vaccine are available globally and out of them two vaccines have been launched in India. To develop natural immunity along with vaccines there is a need to use Ayurvedic drugs as explained above as well as mentioned in the guideline issued by the Government of India Ministry of Health and Family welfare as a preventive measure. For the prevention of contagious disease Rasayana and Panchakarma therapies are clearly mentioned in Ayurveda classics. Corona is mainly attacking the immune system, those with low immunity power come under the risk of this disease so to get rid of this disease, we should use those Dravayas which are useful to improve the immune system. Rasayana maintains the optimum level of tissues and helps to provide good immunity. Rasayana Dravayas act at the level of Agni, Dosha, Dhatu, Srotas (body channels) thus helps in breaking the pathogenesis of disease by removing vitiation of body channels. The use of Rasayana is helpful to increase the immunity of the person to keep away from the disease and also reverse the disease process $\&$ prevents the re-occurrence.

\section{CONCLUSION}

Corona is a life-threatening disease. Till now there is no report of any clinically approved antiviral drugs or vaccines that are effective against COVID - 19. It is the challenge to the entire human population to survive and defeat the disease. All world health system branches are searching how to manage and prevent this disorder. Ayurveda also contributes by giving several drugs information which is useful for control and treating these disorders. The utility of Rasayana Chikitsa is vast and very effective in the prevention as well as management of COVID - 19 disease. This practice can surely bring permanent solutions to different problems facing the current communicable disease. The Conclusion of all these studies indicate that Rasayana has a definite role to play in the maintenance and prevention of health by act on immunity. appropriate use of $R a$ sayana can control the spreading of corona.

\section{REFERENCES}

1. https://www.worldometers.info/coronavirus

2. https://www.who.int/news-room/fact-sheets/detail/middle-east-respiratory-syndrome-coronavirus-(mers-cov)

3. Wu C., Chen X., Cai Y., Xia J., Zhou X., Xu S. Risk factors associated with acute respiratory distress syndrome and death in patients with coronavirus disease 2019 pneumonia in Wuhan, China. JAMA Int Med, 2020.

4. Chauhan VP, Dutt B, Vyas M, Gupta SK. Effect of immune-modulators (Rasayana Dravya) in Janapadodhwansa WSR to COVID - 19. J Ayu Herb Med 2020;6(1):26- 29.

5. $\mathrm{Xu} \mathrm{X,} \mathrm{Chen} \mathrm{P}$, et al. "Evolution of the novel coronavirus from the ongoing Wuhan outbreak and modeling of its spike protein for risk of human transmission". Science China Life Sciences. (March 2020). 63 (3): 457-460.

6. Q. Ye, B. Wang, and J. Mao, "The pathogenesis and treatment of the 'Cytokine Storm' in COVID-19,' Journal of infection, vol. 80, no. 6, pp. 607-613, 2020.

7. Zhou F., Yu T., Du R., Fan G., Liu Y., Liu Z. Clinical course and risk factors for mortality of adult in patients with COVID-19 in Wuhan, China: a retrospective cohort study. Lancet. 2020;395(10229):1054-1062. doi: 10.1016/S0140-6736(20)30566-3.

8. Kermani Kordzadeh Elaheh et.al. Pathogenesis, clinical manifestation and complications of corona virus disease 2019 (COVID-19); future microbiology ;2020 August 
9. T. P. Velavan and C. G. Meyer, "The COVID-19 epidemic," Tropical Medicine \& International Health, vol. 25, no. 3, pp. 278-280, 2020.

10. Sharma PV (1998), Charaka Samhita of Acharya Charaka, Chaukhambha Orientalia Publications, Chikitsa Sthana, 1/1 Varanasi.

11. Anakkleelil. S. Gopala Pillai. Sharangadhara Samhita by Sharangadhara, Purva Khanda; 6th edition; Chapter 4; verse 13

12. Chauhan VP, Dutt B, Vyas M, Gupta SK; Effect of immune-modulators (Rasayana Dravya) in Janapadodhwansa WSR to COVID - 19; J Ayu Herb Med; 2020;6(1)

13. B. Mahadev et al. Critical Review of Medhya Rasayan drugs mentioned in Ayurveda-traditional Indian medicine; International Journal of Ayurveda and Pharma Research; June 2016; Vol 4 Issue 6.

14. Kuchewar V. Vaishali et.al. Evaluation of antioxidant potential of Rasayan drugs in healthy human volunteers; Ayu; 2014 Jan - Mar;35(1);46-49.

15. Gulati K, Ray A, Debnath PK and Bhattacharya SK; Immunomodulatory Indian medicinal plants; Journal of Natural Remedies;2002; 2(2):121-131.

16. D. Chaussabel, V. Pascual, J. Banchereau Assessing the human immune system through blood transcriptomics BMC Biol, 8 (2010), p. 84 Google Scholar.

17. Chauhan VP, Dutt B, Vyas M, Gupta SK; Effect of immune-modulators (Rasayana Dravya) in Janapadodhwansa WSR to COVID-19 - 19; J Ayu Herb Med; 2020;6(1)

18. Dr. Rakesh Shukla, Dr. Jinesh Jain et al. Role Of Rasayan In Communicable Disease (Janapadodhwamsa) European Journal Of Pharmaceutical And Medical Research (EJPMR), 2019,6(1), 232-234

19. Mair CE, Liu R, Atanasov AG, Schmidtke M, Dirsch VM, Rollinger JM. Antiviral and anti-proliferative invitro activities of piperamides from black pepper. Planta Med. 2016; 82: S1-S381.

20. Srivastava AK, Chaurasia JP et al. Role of Medicinal Plants of Traditional Use in Recuperating Devastating COVID-19 Situation, Medicinal \& Aromatic Plants (Los Angeles), Vol.9 Iss.5 No:359

21. Pandey Kashinatha, Chaturvedi Natha Gorakha; Charak Samhita of Agnivesa; Part2; Sutra Sthana1, verse 36; Chaukhamba Bharti Academy, Varanasi;2011; pg. 80.22

22. Kaur, S., S. Arora, K. Kaur and S. Kumar; The Invitro antimutagenic activity of Triphalaan Indian herbal drug; Food ChemToxicol;2002;40(4): 527-534.23
23. Mi-Sun Y, June L, Jin Moo L, Younggyu K, YoungWon C, JunGoo J, et al. Identification of Myricetin and Scutellarein as Novel Chemical Inhibitors of the SARS Coronavirus Helicase. nsP13 J Ethnopharmacol. 2008;118: 79-85.

24. Keivan Z, Boon-T, Sing-Sin S, Pooi-Fong W, Mohd Rais M, Sazaly A. Novel antiviral activity of baicalein against dengue virus. BMC Complem Altern M. 2012; 12: 214

25. https://www.ayush.gov.in/ayush-guidelines

26. Rastogi Sanjeev et al. COVID-19 pandemic: A pragmatic plan for Ayurveda intervention; J Ayurveda Integr Med; 2020 Apr 23

\section{Source of Support: Nil \\ Conflict of Interest: None Declared}

How to cite this URL: Pooja Pawar et al: Role of Rasayana In Relation To Corona Virus (Covid - 19) Diseases. International Ayurvedic Medical Journal \{online\} 2021 \{cited February, 2021\} Available from: http://www.iamj.in/posts/images/upload/459 465.pdf 